\title{
Analisis Struktur Ekonomi dan Sektor Unggulan Kabupaten Aceh Besar
}

\author{
Irwan Safwadi ${ }^{* 1}$, Marah Sutan Rangkuti ${ }^{2}$ \\ ${ }^{1}$ Program Studi Ekonomi Pembangunan, Fakultas Ekonomi Universitas Abulyatama, Aceh Besar, \\ 23372, Indonesia. \\ 2 Program Studi Akuntansi, Fakultas Ekonomi Universitas Abulyatama, Aceh Besar, 23372, \\ Indonesia. \\ *Email korespondensi: irwan_safwadi@yahoo.com ${ }^{1}$
}

Diterima 2 Maret 2018; Disetujui 11 April 2018; Dipublikasi 30 April 2018

\begin{abstract}
Development policy through the optimization of local resource potential is a need that needs to be prepared in order to encourage the acceleration of regional economic growth. Identify changes in economic structure and determine the leading economic sectors including one of the efforts to accelerate the process of achieving economic growth. This study aims to analyze changes in economic structure and determine the leading economic sectors in Aceh Besar District. The data used is secondary data in the form of time series data (time series) Gross Regional Domestic Product (GRDP) of Aceh Besar Regency based on constant prices and GRDP of Aceh Province based on the constant price of 2012-2016. The analyzer used is ShiftShare. During the last five years, Aceh Besar's economic structure based on Shift-Share was only donated by Aceh Province by 19.60 percent. Furthermore, the industry mix contributed 17.89 percent. The leading economic sectors accounted for 62.50 percent of Aceh Besar economic structure changes. The result of Shift Share analysis shows that most of Aceh Besar Regency's economic sector is one of the leading sectors that grow fast in economy in Aceh Province. Only the electricity and gas procurement sector does not excel in Aceh Besar.
\end{abstract}

\section{Keywords: GRDP, Leading Sector, shift share}

Abstrak: Kebijakan pembangunan melalui optimalisasi potensi sumberdaya lokal merupakan kebutuhan yang perlu dipersiapkan dalam rangka mendorong percepatan pertumbuhan ekonomi daerah. Mengidentifikasi perubahan struktur ekonomi dan menentukan sektor-sektor ekonomi unggulan termasuk salah satu upaya mempercepat proses pencapaian pertumbuhan ekonomi. Penelitian ini bertujuan menganalisis perubahan struktur ekonomi dan menentukan sektor-sektor ekonomi unggulan di Kabupaten Aceh Besar. Data yang digunakan adalah data sekunder berupa data runtun waktu (time series) PDRB Kabupaten Aceh Besar berdasarkan harga konstan dan PDRB Provinsi Aceh berdasarkan harga konstan tahun 2012-2016. Alat analisis yang digunakan adalah Shift-Share. Selama lima tahun terakhir, struktur ekonomi Aceh Besar berdasarkan Shift-Share hanya disumbangkan Provinsi Aceh sebesar 19,60 persen. Lebih lanjut, bauran industri menyumbang sebesar 17,89 persen. Adapun sektor-sektor ekonomi unggulan menyumbang sebesar 62,50 persen terhadap perubahan struktur ekonomi Aceh Besar. Hasil analisis Shift Share menunjukkan bahwa sebagian sektor ekonomi Kabupaten Aceh Besar termasuk sektor unggulan yang tumbuh cepat pada perekonomian di Provinsi Aceh. Hanya sektor pengadaan listrik dan gas yang tidak unggul di Aceh Besar.

Kata kunci : PDRB, sektor unggulan, shift share 
Pembangunan pada hakekatnya suatu upaya sistematis dan terencana yang dilaksanakan oleh seluruh komponen masyarakat untuk mewujudkan perubahan ke arah yang lebih baik. Tujuan akhir pembangunan adalah untuk meningkatkan kualitas hidup masyarakat secara berkelanjutan yang ditempuh melalui pemanfaatan sumber daya yang tersedia secara optimal, efisien, efektif, dan akuntabel. Tujuan dan cita-cita tersebut diwujudkan melalui perencanaan yang berkualitas, sinergis, dan kredibel yang memuat langkah-langkah strategis, taktis, dan praktis yang memperhatikan potensi sumberdaya dan tantangan yang sedang dihadapi.

Aceh Besar merupakan salah satu kabupaten di Provinsi Aceh yang berbatasan langsung dengan ibukota Provinsi Aceh. Sejak abab 11, Aceh Besar menjadi pintu gerbang nusantara bagi perdagangan. Wilayah Aceh Besar yang strategis di ujung barat Sumatera menjadi salah satu kabupaten yang menjanjikan potensi bagi investasi. Disisi lainnya, daerah ini dihadapkan tantangan pembangunan yang besar, seperti kemiskinan yang mencapai 15,5 persen tahun 2017 dan laju pertumbuhan ekonomi yang sebesar 4,05 persen tahun 2016 .

Untuk mendukung pertumbuhan ekonominya, Kabupaten Aceh Besar perlu mengidentifikasi sektor-sektor mana yang dapat diunggulkan. Pemerintah Kabupaten Aceh Besar perlu menetapkan sektor-sektor ekonomi prioritas sebagai unggulan daerah serta mampu bersaing dengan sektor ekonomi lainnya di Provinsi Aceh. Hal ini dipandang penting sebelum intervensi kebijakan dan upaya strategis ditempuh dalam pengembangan sektor-sektor ekonomi di Kabupaten Aceh Besar.

Penelitian ini bertujuan menganalis perubahan struktur ekonomi dan menentukan sektor-sektor unggulan di Kabupaten Aceh Besar sehingga dapat dijadikan pertimbangan dalam perumusan kebijakan dan perencanaan pembangunan di Kabupaten Aceh Besar.

\section{KAJIAN PUSTAKA}

\section{Sektor Unggulan}

Sektor unggulan adalah sektor atau kegiatan ekonomi yang mempunyai potensi, kinerja, prospek yang lebih baik dibandingkan dengan sektor lainnya. Sektor unggulan mampu menggerakkan kegiatan usaha ekonomi turunan lainnya, sehingga dapat tercipta kemandirian pembangunan wilayah. Suatu daerah akan mempunyai sektor unggulan apabila daerah tersebut dapat memenangkan persaingan pada sektor yang sama dengan daerah lain sehingga dapat menghasilkan ekspor (Aswandi dan Kuncoro, 2002).

Sektor unggulan dapat menjadi dasar pertimbangan perencanaan pembangunan daerah di masa yang akan datang. Sektor unggulan memberikan keunggulan kompetitif atau komparatif yang selanjutnya dapat mendorong pengembangan ekspor barang maupun jasa pada suatu wilayah sehingga berdampak pada peningkatan pendapatan daerah.

Menurut Rachbini (2001:54), terdapat empat syarat agar suatu sektor tertentu menjadi sektor unggulan/prioritas, yakni :

1. Sektor tersebut harus menghasilkan produk yang mempunyai permintaan yang cukup besar, sehingga laju pertumbuhan berkembang cepat akibat dari efek permintaan tersebut.

2. Karena ada perubahan teknologi yang 
teradopsi secara kreatif, maka fungsi produksi baru bergeser dengan pengembangan kapasitas yang lebih luas.

3. Harus terjadi peningkatan investasi kembali dari hasil-hasil produksi sektor yang menjadi prioritas tersebut, baik swasta maupun pemerintah.

4. Sektor tersebut harus berkembang, sehingga mampu memberi pengaruh terhadap sektorsektor lainnya.

Selanjutnya faktor ini berkembang lebih lanjut melalui kegiatan investasi dan menjadi tumpuan kegiatan ekonomi. Kriteria sektor unggulan akan sangat bervariasi. Hal ini didasarkan atas seberapa besar peranan sektor tersebut dalam perekonomian daerah, diantaranya : Pertama, sektor unggulan tersebut memiliki laju tumbuh yang tinggi. Kedua, sektor tersebut memiliki angka penyerapan tenaga kerja yang relatif besar. Ketiga, sektor tersebut memiliki keterkaitan antar sektor yang tinggi baik ke depan maupun ke belakang. Keempat, dapat juga diartikan sebagai sektor yang mampu menciptakan nilai tambah yang tinggi.

\section{Produk Domestik Regional Bruto (PDRB )}

Menurut Badan Pusat Statistik (2017), Produk Domestik Regional Bruto (PDRB) yaitu jumlah nilai tambah yang dihasilkan untuk seluruh unit usaha dalam suatu wilayah atau merupakan seluruh jumlah nilai barang \& jasa akhir yang dihasilkan seluruh unit ekonomi di suatu wilayah. PDRB suatu wilayah menggambarkan struktur ekonomi daerah, peranan sektor-sektor ekonomi dan pergeserannya, serta menunjukkan laju pertumbuhan ekonomi, baik secara total maupun persektor. Di dalam menghitung PDRB yang ditimbulkan dari suatu region, ada 3 pendekatan yang digunakan yaitu :

1. PDRB menurut pendekatan produksi, Merupakan jumlah nilai barang atau jasa akhir yang dihasilkan oleh berbagai unit produksi yang berada di suatu wilayah dalam jangka waktu tertentu.

2. PDRB menurut pendekatan pendapatan Merupakan balas jasa yang digunakan oleh faktor-faktor produksi yang ikut serta dalam proses produksi di suatu wilayah dalam waktu tertentu.

3. PDRB menurut pendekatan pengeluaran

Merupakan semua komponen pengeluaran akhir seperti : pengeluaran konsumsi rumah tangga dan lembaga swasta nirlaba, konsumsi pemerintah, pembentukan modal tetap bruto, perubahan stok dan ekspor neto dalam jangka waktu tertentu.

\section{Shift-Share}

Analisis Shift-share merupakan suatu analisis yang dilakukan untuk mengetahui perubahan dan pergeseran sektor atau industri pada perekonomian regional maupun lokal. Analisis Shiftshare menggambarkan kinerja sektor-sektor di suatu wilayah dibandingkan dengan perekonomian nasional. Bila suatu daerah memperoleh kemajuan sesuai dengan kedudukannya dalam perekonomian nasional, maka akan dapat ditemukan adanya shift (pergeseran) hasil pembangunan perekonomian daerah. Selain itu, laju pertumbuhan sektor-sektor di suatu wilayah akan dibandingkan dengan laju pertumbuhan perekonomian nasional beserta sektor-sektornya. Kemudian dilakukan analisis terhadap penyimpangan yang terjadi sebagai hasil dari perbandingan tersebut. Bila penyimpangan 
itu positif, hal itu disebut keunggulan kompetitif dari suatu sektor dalam wilayah tersebut. Variabel atau data yang digunakan dalam analisis Shift share adalah tenaga kerja atau kesempatan kerja, nilai tambah, pendapatan, Pendapatan Regional Domestik Bruto (PDRB), jumlah penduduk, dan variabel lain dalam kurun waktu tertentu.

Alat statistik Shift share pertama kali diperkenalkan oleh Dunn (1960) yang digunakan untuk menjelaskan perubahan ekonomi sebagai kombinasi dari tiga faktor pengaruh: nasional, sektoral dan regional (lokal). Karena kejelasan dan kesederhanaannya, metode ini banyak digunakan dalam analisis pertumbuhan ekonomi regional. Beberapa varian atau modifikasi tambahan dari spesifikasi dasar Shift share telah dibuat dari waktu ke waktu untuk memisahkan perubahan output dari peningkatan produktivitas (Rigby dan Anderson, 1993) dan memperkenalkan total faktor produktivitas (Haynes dan Dinc, 1997). Selain itu, menggabungkan Shift share dengan analisis data regresi untuk menjelaskan dan meramalkan komponen-komponen perubahan (Patterson, 1991), untuk menganalisa efek spesifik dari daerah atau sektor besar (Dinc dan Haynes, 2005), untuk menggabungkan struktur sektoral (Hewings et al, 2008), dll. Sebagian besar baru-baru ini perluasan metode Shift share juga memasukan perspektif struktur spasial, misalnya, Nazara dan Hewings (2004) memperkenalkan interaksi spasial, López (2005) menggunakan dekomposisi spasial perubahan, dan Ramajo dan Márquez (2007) menambahkan tiga efek spasial baru ke dalam analisis shift-share dasar.

Beberapa keunggulan analisa Shift-share, antara lain:
1. Memberikan gambaran mengenai perubahan struktur ekonomi yang terjadi, walau analisis shift-share tergolong sederhana.

2. Memungkinkan seseorang pemula mempelajari struktur perekonomian dengan cepat.

3. Memberikan gambaran pertumbuhan ekonomi dan perubahan struktur dengan cukup akurat.

Disisi lainnya, analisis Shift-share juga memiliki kelemahan, yaitu:

1. Hanya dapat digunakan untuk analisis ex-post.

2. Masalah benchmark berkenaan dengan homothetic change, apakah $\mathrm{t}$ atau $(\mathrm{t}+1)$ tidak dapat dijelaskan dengan baik.

3. Ada data periode waktu tertentu di tengah periode pengamatan yang tidak terungkap.

4. Analisis ini membutuhkan analisis lebih lanjut apabila digunaka untuk peramalan, mengingat bahwa regional shift tidak konstan dari suatu periode ke periode lainnya.

5. Tidak dapat dipakai untuk melihat keterkaitan antarsektor.

6. Tidak ada keterkaitan antar daerah.

Analisis Shift-share menggunakan 3 (tiga) informasi dasar yang berhubungan satu sama lain yaitu :

1. Pertumbuhan ekonomi referensi propinsi atau nasional (national growth effect), yang menunjukkan bagaimana pengaruh pertumbuhan ekonomi nasional terhadap perekonomian daerah.

2. Pergeseran proporsional (proporsional shift) yang menunjukkan perubahan relatif kinerja suatu sektor di daerah tertentu terhadap sektor yang sama di referensi propinsi atau nasional. Pergeseran proporsional (proportional shift) disebut juga pengaruh bauran 
industri (industry mix). Pengukuran ini memungkinkan kita untuk mengetahui apakah perekonomian daerah terkonsentrasi pada indutriindustri yang tumbuh lebih cepat ketimbang perekonomian yang dijadikan referensi.

3. Pergeseran diferensial (differential shift) yang memberikan informasi dalam menentukan seberapa jauh daya saing industri daerah (lokal) dengan perekonomian yang dijadikan referensi. Jika pergeseran diferensial dari suatu industri adalah posisitf, maka industri tersebut relatif lebih tinggi daya saingnya dibandingkan industri yang sama pada perekonomian yang dijadikan referensi. Pergeseran diferensial disebut juga pengaruh keunggulan kompetitif.

\section{METODE PENELITIAN}

\section{Jenis dan Sumber Data}

Sesuai dengan tujuan penelitian, data yang digunakan dalam penelitian ini adalah data sekunder. Data tersebut berupa Produk Domestik Regional Bruto (PDRB) atas dasar harga konstan (ADHK) Kabupaten Aceh Besar menurut lapangan usaha dan PDRB ADHK non-migas Provinsi Aceh menurut lapangan usaha periode 2012-2016. Data ini digunakan untuk analisis perubahan dan pergeseran sektor ekonomi dan menentukan sektor unggulan. Data sekunder ini diperoleh dari Badan Pusat Statistik (BPS) Kabupaten Aceh Besar dan Provinsi Aceh. Penggunaan data harga konstan dengan tahun dasar yang sama agar bobotnya (nilai riilnya) bisa sama dan perbandingan menjadi valid (Tarigan, 2007:86).

\section{Metode Analisis Data}

\section{Analisis shift share}

Analisis shift share digunakan untuk mengetahui perubahan struktur perekonomian Kabupaten Aceh Besar. Hasil analisis shift share dapat menggambarkan kinerja sektor-sektor dalam PDRB Kabupaten Aceh Besar dibandingkan Provinsi Aceh. Melalui analisis shift share, maka pertumbuhan ekonomi dan pergeseran struktural perekonomian wilayah Kabupaten Aceh Besar ditentukan oleh tiga komponen, yaitu:

1. Nasional Share (NS), yang digunakan untuk mengetahui pertumbuhan atau pergeseran struktur perekonomian Kabupaten Aceh Besar dengan melihat nilai PDRB Kabupaten Aceh Besar sebagai daerah pengamatan pada periode awal yang dipengaruhi oleh pergeseran pertumbuhan perekonomian Provinsi Aceh. Hasil perhitungan Nasional Share akan menggambarkan peranan wilayah Provinsi Aceh yang mempengaruhi pertumbuhan perekonomian Kabupaten Aceh Besar. Jika pertumbuhan Kabupaten Aceh Besar sama dengan pertumbuhan Provinsi Aceh maka peranannya terhadap provinsi tetap.

2. Proportional Shift (PS) adalah pertumbuhan nilai tambah bruto suatu sektor $i$ pada Kabupaten Aceh Besar dibandingkan total sektor di tingkat Provinsi Aceh.

3. Differential Shift (DS) adalah perbedaan antara pertumbuhan ekonomi Kabupaten Aceh Besar dan nilai tambah bruto sektor yang sama di tingkat Provinsi Aceh. 
Secara matematis, NS, PS, dan DS dapat diformulasikan sebagai berikut (Tarigan, 2007:88; Sjafrizal, 2008:91):

1. National Share (NS) $\mathrm{NS}_{i \mathrm{KL}, \mathrm{t}}=\mathrm{PDRB}_{i \mathrm{KL}, \mathrm{tw}}$

$$
\times\left(\frac{\Sigma \mathrm{PDRB}_{\mathrm{PA}, \mathrm{tk}}}{\sum \mathrm{PDRB}_{\mathrm{PA}, \mathrm{tw}}}-1\right)
$$

2. Proportional Shift (PS)

$$
\begin{aligned}
\mathrm{PS}_{i \mathrm{KL}, \mathrm{t}}=\mathrm{PDRB}_{i \mathrm{KL}, \mathrm{tw}} & \\
\times & {\left[\left(\frac{\mathrm{PDRB}_{i \mathrm{PA}, \mathrm{tk}}}{\mathrm{PDRB}_{i \mathrm{PA}, \mathrm{tw}}}\right)\right.} \\
& \left.-\left(\frac{\Sigma \mathrm{PDRB}_{\mathrm{PA}, \mathrm{tk}}}{\sum \mathrm{PDRB}_{\mathrm{PA}, \mathrm{tw}}}\right)\right]
\end{aligned}
$$

3. Differential Shift (DS)

$$
\begin{aligned}
\mathrm{DS}_{i \mathrm{KL}, \mathrm{t}}=\mathrm{PDRB}_{i \mathrm{KL}, \mathrm{tw}} & \times\left[\left(\frac{\mathrm{PDRB}_{i \mathrm{KL}, \mathrm{tk}}}{\mathrm{PDRB}_{i \mathrm{KL}, \mathrm{tw}}}\right)\right. \\
& \left.-\left(\frac{\mathrm{PDRB}_{i \mathrm{PA}, \mathrm{tk}}}{\mathrm{PDRB}_{i \mathrm{PA}, \mathrm{tw}}}\right)\right]
\end{aligned}
$$

di mana:

PA = Provinsi Aceh sebagai wilayah referensi yang lebih tinggi jenjangnya.

$\mathrm{KL}=$ Kabupaten Aceh Besar sebagai wilayah analisis.

$\mathrm{PDRB}=$ Nilai tambah bruto

$i=$ Sektor tertentu dalam PDRB

tk $=$ Tahun akhir (Tahun 2014)

$\mathrm{tw}=$ Tahun awal (Tahun 2010)

Perubahan (pertumbuhan) nilai tambah bruto sektor tertentu ( $i$ ) dalam PDRB Kabupaten Aceh Besar merupakan penjumlahan NS, PS, dan DS sebagai berikut:

$$
\Delta \mathrm{Y}_{\mathrm{iKL}, \mathrm{t}}=\mathrm{NS}_{\mathrm{iKL}, \mathrm{t}}+\mathrm{PS}_{\mathrm{iKL}, \mathrm{t}}+\mathrm{DS}_{\mathrm{iKL}, \mathrm{t}}
$$

Kedua komponen shift, yaitu PS dan DS memisahkan unsur-unsur pertumbuhan regional yang bersifat eksternal dan internal. PS merupakan akibat pengaruh unsur-unsur eksternal yang bekerja secara nasional (Provinsi), sedangkan DS adalah akibat dari pengaruh faktor-faktor yang bekerja di dalam daerah yang bersangkutan.

Sektor-sektor di Kabupaten Aceh Besar yang memiliki DS positif memiliki keunggulan komparatif terhadap sektor yang sama pada di Provinsi Aceh. Selain itu, sektor-sektor yang memiliki nilai DS positif berarti bahwa sektor tersebut terkonsentrasi di Kabupaten Aceh Besar dan mempunyai pertumbuhan yang lebih cepat dibandingkan dengan daerah lainnya. Apabila nilai DS negatif, maka tingkat pertumbuhan sektor tersebut relatif lamban.

\section{HASIL DAN PEMBAHASAN}

\section{Perkembangan PDRB}

Perkembangan aktivas ekonomi yang terlihat dari produksi barang dan jasa di Kabupaten Aceh Besar dan Provinsi Aceh cenderung meningkat. Kurun waktu 2012-2016, pertumbuhan PDRB Kabupaten Aceh Besar rata-rata 7,79 persen setiap tahunnya (lihat gambar 1). Sampai tahun 2016, PDRB Kabupaten Aceh Besar berdasarkan ADHK mencapai Rp.10.960.105 juta. Angka PDRB ini meningkat drastis dibandingkan tahun 2012 yang sebesar Rp.8.118.767 juta. Demikian juga halnya dengan Provinsi Aceh, PDRB Aceh berdasarkan ADHK mencapai Rp.116.386.730,7 juta tahun 2016. Adapun tahun 2012, PDRB Aceh masih sebesar Rp.108.914.897,80 juta. Periode 2012-2016, pertumbuhan PDRB Aceh meningkat rata-rata 1,67 persen setiap tahunnya.

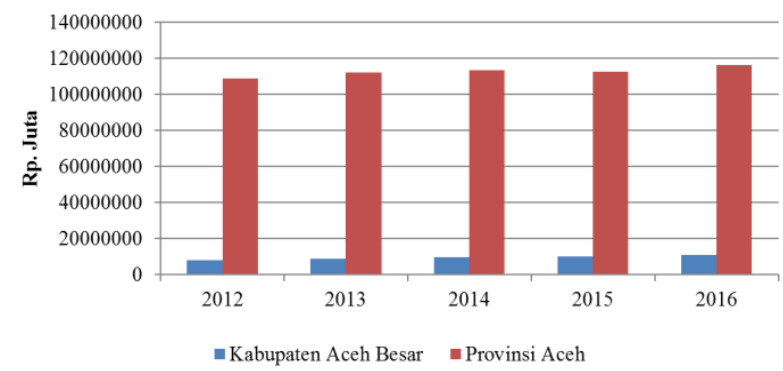

Sumber: BPS Aceh, 2017 (diolah)

Gambar 1. Perkembangan PDRB Kabupaten Aceh Besar dan Provinsi Aceh, Tahun 2012-2016 


\section{Analisis Shift Share}

Analisis Shift share dapat memberikan gambaran perbandingan kinerja pertumbuhan secara sektoral/lapangan usaha. Selama lima tahun terakhir, pertumbuhan masing-masing lapangan usaha di Kabupaten Aceh Besar dan Provinssi Aceh masih berkisar rata-rata di bawah dari 1 persen. Untuk Kabupaten Aceh Besar, hanya lapangan usaha pertambangan dan penggalian yang memperlihatkan pertumbuhan yang negatif. Adapun lapangan usaha lainnya memperlihatkan pertumbuhan yang positif, meskipun pertumbuhan yang lambat.

Kondisi yang sama juga terjadi di Provinsi Aceh. Selama lima tahun terakhir, pertumbuhan lapangan usaha cenderung lambat. Bahkan, lapangan usaha pertambangan dan penggalian, dan industri pengolahan tumbuh negatif. Rendahnya pertumbuhan tersebut sangat beralasan mengingat aktivitas pertambangan dan penggalian yang semakin terbatas di wilayah-wilayah penghasil minyak dan gas serta kurang berkembangnya industri pengolahan di Aceh. Perbandingan pertumbuhan lapangan usaha di Kabupaten Aceh Besar dan Provinsi Aceh sebagaimana terlihat pada tabel 1 .

Tabel 1. Perbandingan Pertumbuhan Sektoral di Kabupaten Aceh Besar dan Provinsi Aceh Berdasarkan Shift Share

\begin{tabular}{|c|c|c|c|}
\hline No & Lapangan Usaha & $\mathbf{r}_{\mathrm{ii}}$ & $\mathbf{r}_{\text {in }}$ \\
\hline 1 & Pertanian, kehutanan dan perikanan & 0,51 & 0,17 \\
\hline 2 & Pertambangan dan pengalian & $-0,01$ & $-0,46$ \\
\hline 3 & Industri pengolahan & 0,41 & $-0,34$ \\
\hline 4 & Pengadaan listrik dan gas & 0,30 & 0,34 \\
\hline 5 & $\begin{array}{l}\text { Pengadaan air, pengelolaan } \\
\text { sampah, limbah, dan daur ulang }\end{array}$ & 0,54 & 0,30 \\
\hline 6 & Kontruksi & 0,32 & 0,31 \\
\hline 7 & $\begin{array}{l}\text { Perdagangan besar dan eceran, } \\
\text { reparasi mobil dan sepeda motor }\end{array}$ & 0,36 & 0,18 \\
\hline 8 & Transportasi dan pergudangan & 0,38 & 0,09 \\
\hline 9 & Penyediaan akomodasi dan makan & 0,43 & 0,31 \\
\hline
\end{tabular}

\begin{tabular}{|c|c|c|c|}
\hline No & Lapangan Usaha & $\mathbf{r}_{\mathrm{ii}}$ & $\mathbf{r}_{\text {in }}$ \\
\hline & minum & & \\
\hline 10 & Informasi dan komunikasi & 0,18 & 0,15 \\
\hline 11 & Jasa keuangan dan asuransi & 0,46 & 0,22 \\
\hline 12 & Real estat & 0,39 & 0,31 \\
\hline 13 & Jasa perusahaan & 0,28 & 0,24 \\
\hline 14 & $\begin{array}{l}\text { Perusahaan adminitrasi pemerintah, } \\
\text { pertahanan dan jaminan sosial }\end{array}$ & 0,38 & 0,29 \\
\hline 15 & Jasa pendidikan & 0,31 & 0,30 \\
\hline 16 & Jasa kesehatan dan kegiatan sosial & 0,30 & 0,29 \\
\hline 17 & Jasa lainnya & 0,29 & 0,25 \\
\hline
\end{tabular}

Hasil perhitungan analisis shift share PDRB Kabupaten Aceh Besar tahun 2012-2016 tercantum pada tabel 2. Komponen Nasional Share (NS) memiliki nilai positif yang artinya mengalami peningkatan kinerja sebesar Rp. 556.967,59 juta rupiah, atau 19,60 persen terhadap pertumbuhan struktur perekonomian Kabupaten Aceh Besar. Hal ini dikarenakan semua sektor ekonomi Kabupaten Aceh Besar bernilai positif dalam memberikan perannya terhadap pertambahan PDRB Kabupaten Aceh Besar seandainya pertumbuhannya sama dengan laju pertumbuhan PDRB Provinsi Aceh.

Nilai Kompenen Proportional Shift (PS) sektor Kabupaten Aceh Besar ada yang bernilai negatif dan positif. Nilai PS positif, berarti perekonomian Kabupaten Aceh Besar berspesialisasi pada sektor yang sama yang tumbuh cepat pada perekonomian Provinsi Aceh. Sebaliknya apabila Nilai PS negatif, berarti perekonomian Kabupaten Aceh Besar berspesialisasi pada sektor yang sama dan tumbuh lambat pada perekonomian Provinsi Aceh. 
Tabel 2. Perbandingan Pertumbuhan Sektoral di Kabupaten Aceh Besar dan Provinsi Aceh Berdasarkan Shift Share

\begin{tabular}{|c|c|c|c|c|c|}
\hline No & Lapangan Usaha & $\begin{array}{l}\text { Nasional } \\
\text { Share } \\
\text { (NS) }\end{array}$ & $\begin{array}{l}\text { Proportional } \\
\text { Shift } \\
\text { (PS) }\end{array}$ & $\begin{array}{l}\text { Differential } \\
\text { Shift } \\
\text { (DS) }\end{array}$ & $\begin{array}{l}\text { Total } \\
(\Delta Y)\end{array}$ \\
\hline 1 & Pertanian, kehutanan dan perikanan & 119066.32 & $174,179.13$ & $595,999.25$ & $889,244.70$ \\
\hline 2 & Pertambangan dan pengalian & 50660.50 & $-387,801.94$ & $332,592.44$ & $-4,549.00$ \\
\hline 3 & Industri pengolahan & 12658.85 & $-75,642.48$ & $139,448.33$ & $76,464.70$ \\
\hline 4 & Pengadaan listrik dan gas & 419.97 & $1,674.50$ & -262.67 & $1,831.80$ \\
\hline 5 & $\begin{array}{l}\text { Pengadaan air, pengelolaan sampah, limbah } \\
\text { dan daur ulang }\end{array}$ & 207.22 & 687.12 & 745.36 & $1,639.70$ \\
\hline 6 & Kontruksi & 77313.50 & $274,446.39$ & $4,186.31$ & $355,946.20$ \\
\hline 7 & $\begin{array}{l}\text { Perdagangan besar da eceran;reparasi mobil } \\
\text { dan sepeda motor }\end{array}$ & 96553.03 & $155,073.67$ & $255,525.39$ & $507,152.10$ \\
\hline 8 & Transportasi dan pergudangan & 74270.44 & $18,942.68$ & $317,734.98$ & $410,948.10$ \\
\hline 9 & Penyediaan akomodasi dan makan minum & 7441.42 & $26,153.06$ & $13,061.41$ & $46,655.90$ \\
\hline 10 & Informasi dan komunikasi & 27950.48 & $32,213.91$ & $13,165.71$ & $73,330.10$ \\
\hline 11 & Jasa keuangan dan asuransire & 6746.44 & $14,692.20$ & $23,820.96$ & $45,259.60$ \\
\hline 12 & Real estat & 28405.28 & $99,099.11$ & $35,738.01$ & $163,242.40$ \\
\hline 13 & Jasa perusahaan & 1891.03 & $4,675.61$ & $1,280.45$ & $7,847.10$ \\
\hline 14 & $\begin{array}{l}\text { Perusahaan adminitrasi pemerintah, } \\
\text { pertahanan dan jaminan sosial }\end{array}$ & 29515.89 & $96,581.69$ & $35,279.21$ & $161,376.80$ \\
\hline 15 & Jasa pendidikan & 7897.88 & $26,364.50$ & $1,938.62$ & $36,201.00$ \\
\hline 16 & Jasa kesehatan dan kegiatan sosial & 9621.81 & $30,637.92$ & $1,747.97$ & $42,007.70$ \\
\hline 17 & Jasa lainnya & 6347.53 & $16,534.91$ & $3,856.66$ & $26,739.10$ \\
\hline \multicolumn{2}{|c|}{ Produk Domestik Regional Bruto } & $556.967,59$ & $508.511,98$ & 1775858,39 & $2.841 .337,96$ \\
\hline \multicolumn{2}{|r|}{ Share (\%) } & 19,60 & 17,89 & 62,50 & 100 \\
\hline
\end{tabular}

Sumber: BPS Aceh, 2017 (diolah)

Selama periode tahun 2012-2016, kinerja komponen PS Kabupaten Aceh Besar ternyata mengalami peningkatan peranan yang cukup memadai, yaitu sebesar Rp. 508.511,98 juta rupiah atau 17,89 persen terhadap pertumbuhan ekonomi Kabupaten Aceh Besar. Hal ini disebabkan karena sebagian besar lapanga usaha Kabupaten Aceh Besar memiliki nilai komponen pertumbuhan PS yang positif kecuali lapangan usaha pertambangan dan penggalian serta industri pengolahan yang memiliki nilai negatif Adapun lapangan usaha dengan nilai PS positif secara berturut yaitu: (1) Sektor perdagangan besar dan eceran; reparasi mobil dan sepeda motor, (2) Sektor bangunan, (3) Sektor transportasi dan pergunangan, (4) Jasa kesehatan dan kegiatan sosial, (5) Sektor informasi dan komunikasi, (6) Sektor pertanian, kehutanan dan perikanan, (7) Sektor administrasi pemerintahan, pertahanan, dan jaminan sosial wajib, (8) Sektor real estate, (9) Sektor penyediaan akomodasi dan makan minum, (10) Sektor jasa keuangan dan asuransi, (11) Sektor jasa lainnya, (12) Sektor jasa pendidikan, (13) Sektor jasa perusahaan, (14) Sektor pengadaan listrik dan gas, terakhir (15) Sektor pengadaan air, pengelolaan sampah, limbah dan daur ulang.

Nilai DS sektor perekonomian Kabupaten Aceh Besar selama periode tahun 2012-2016 ada yang positif dan negatif. Nilai DS positif, berarti bahwa terdapat sektor ekonomi Kabupaten Aceh Besar tumbuh lebih cepat dibandingkan sektor yang sama di tingkat Provinsi Aceh. Sedangkan nilai DS negatif, berarti sektor tersebut tumbuh lebih lambat dibandingkan sektor yang sama di tingkat Provinsi Aceh.

Secara agregat, komponen DS ternyata bernilai positif atau mengalami peningkatan kinerja sebesar Rp. $1.775 .858,39$, atau 62,50 persen terhadap pertumbuhan ekonomi Kabupaten Aceh Besar. 
Walaupun demikian tapi masih terdapat satu sektor dalam perekonomian Kabupaten Aceh Besar yang memiliki nilai DS negatif, yaitu sektor Pengadaan listrik dan gas. Sektor tersebut merupakan sektor yang kurang kompetitif yang memiliki pertumbuhan yang lebih rendah dibandingkan dengan sektor yang sama di tingkat Provinsi Aceh, sehingga kurang berpotensi untuk dikembangkan dalam memacu pertumbuhan PDRB Kabupaten Aceh Besar. Sedangkan sektor lainnya memiliki nilai DS positif, sehingga sektor-sektor tersebut pertumbuhannya lebih cepat dibandingakan sektor yang sama ditingkat Provinsi Aceh .

Kedua komponen shift ini memisahkan unsurunsur pertumbuhan Kabupaten Aceh Besar yang bersifat intern dan ekstern, di mana PS dari pengaruh unsur-unsur luar yang bekerja dalam Provinsi Aceh dan DS adalah akibat dari pengaruh faktor-faktor yang bekerja di dalam Kabupaten Aceh Besar.

\section{KESIMPULAN DAN SARAN}

\section{Kesimpulan}

Berdasarkan hasil perhitungan Shift share, selama lima tahun terakhir, struktur ekonomi Aceh Besar hanya disumbangkan Provinsi Aceh sebesar 19,60 persen. Kemudian, dari komponen bauran industri menyumbang sebesar 17,89 persen. Lapangan usaha atau sektor-sektor ekonomi unggulan berperan penting dalam menyumbang pertumbuhan ekonomi Aceh Besar, yaitu sebesar 62,50 persen Hasil analisis Shift Share menunjukkan bahwa hanya sektor pengadaan listrik dan gas yang tidak unggul di Aceh Besar. Sebagian sektor ekonomi Kabupaten Aceh Besar termasuk sektor unggulan yang tumbuh cepat pada perekonomian di Provinsi Aceh. Hal ini menunjukkan bahwa lapangan tersebut sangat kompetitif dan tumbuh cepat pada perekonomian di Provinsi Aceh,

\section{Saran}

Berdasarkan hasil pembahasan di atas, penulis menyarankan beberapa hal untuk pihak-pihak terkait, yaitu:

1. Pemerintah Kabupaten Aceh Besar dalam upaya meningkatkan pertumbuhan ekonomi agar lebih mengutamakan pengembangan sektor-sektor ekonomi unggulan dengan tidak mengabaikan sektor lain dalam perencanaan dan pelaksanaan pembangunan ekonomi di Kabupaten Aceh Besar.

2. Sektor perdagangan besar dan eceran; reparasi mobil dan sepeda motor, sektor transportasi dan pergudangan, sektor informasi dan komunikasi yang ternyata merupakan sektor unggulan dalam perekonomian Kabupaten Aceh Besar perlu mendapatkan prioritas pengembangan, sehingga memberikan dampak yang tinggi bagi peningkatan pendapatan masyarakat dan lapangan pekerjaan.

3. Penelitian ini masih terbatas pada tahapan menentukan sub sektor unggulan, kepada peneliti lainnya disarankan untuk melanjutkan penelitian ini sampai pada tahapan menentukan komoditi unggulan.

\section{DAFTAR PUSTAKA}

Aswandi, Haerul dan Kuncoro, M. (2002). Evaluasi Penetapan Kawasan Andalan: Studi Empiris Di Kalimantan Selatan 1993-199, Jurnal Ekonomi dan Bisnis Indonesia. 
Badan Pusat Statitik. (2017). Produk Domestik Regional Bruto Kabupaten Aceh Besar Menurut Lapangan Usaha 2012-2016. Aceh Besar.

Badan Pusat Statitik. (2017). Produk Domestik Regional Bruto Provinsi Aceh Menurut Lapangan Usaha 2012-2016. Banda Aceh.

Dinc, M., Haynes, K. (2005). Productivity, International Trade and Reference Area Interactions in Shift-Share Analysis: Some Operational Notes. Growth and Change, 36(3), 374-394.

Dunn, E. S. (1960). A Statistical and Analytical Technique for Regional Analysis. Papers of the Regional Science Association, 6, 97-112.

Haynes, K., Dinc, M. (1997). Productivity Change in Manufacturing Regions: A Multifactor/Shift-Share Approach. Growth and Change, 28, pp.201-221.

Hewings, G.J.D., Márquez, M. A., Ramajo, J. (2008). Incorporating Sectoral Structure into Shift-Share Analysis, EU-REAL Disscution Paper.

Nazara, S., Hewings, G.J.D., 2004. Spatial Structure and Taxonomy of Decomposition in shift-share analysis. Growth and Change, 35, pp. 476-490.

Patterson, M.G. (1991). A Note on the Formulation of a Full-Analogue Regression Model of the Shift-Share Method. Journal of Regional Science, 31, pp. 211-216.

Rigby, D.L, Anderson, W.P. (1993). "Employment Change, Growth and
Productivity in Canadian Manufacturing: An Extension and Application of ShiftShare Analysis. Canadian Journal of Regional Science, 16, pp. 69-88.

Sjafrizal, (2008). Ekonomi Regional: Teori dan Aplikasi, Padang: Baduose Media.

Tarigan, R. (2007). Ekonomi Regional, Teori dan Aplikasi. Jakarta: Bumi Aksara.

- How to cite this paper :

Safwadi, I., \& Rangkuti, M. S. (2018). Analisis Struktur Ekonomi dan Sektor Unggulan Kabupaten Aceh Besar. Jurnal Humaniora, 2(1), 39-48. 